\title{
EDUKASI PENGENALAN JURNALISTIK KEPADA GENERASI DIGITAL
}

\author{
Ahmad Junaidi ${ }^{1}$, Riris Loisa ${ }^{2}$, dan Sinta Paramita $^{2}$ \\ ${ }^{1}$ Prodi Ilmu Komunikasi, Universitas Tarumanagara \\ Surel: ahmadd@fikom.untar.ac.id \\ ${ }^{2}$ Prodi Ilmu Komunikasi, Universitas Tarumanagara \\ Surel: ririsl@fikom.untar.ac.id \\ ${ }^{3}$ Prodi Ilmu Komunikasi, Universitas Tarumanagara \\ Surel: sintap@fikom.untar.ac.id
}

\begin{abstract}
The digital generation is a generation whose lives depend almost entirely on internet access. The ease of accessing information has both negative and positive sides. The negative side is that the digital era is a generation that is prone to cybercrime and is easily exposed to hoaxes through internet networks. There has been a lot of research in Communication Science that discusses the negative side of technological development. But on the other hand, the digital generation can create exciting content through social media. Kanaan Christian Senior High School initiated this potential to develop extracurricular activities that could improve students' abilities in journalism. The problem arises when there are no teaching resources that can educate students in the world of journalism. Therefore, the Faculty of Communication Sciences at Tarumanagara University seeks to inform people's lives through community service activities (PKM), to assist the Kanaan Christian High School in carrying out journalistic extracurricular activities by providing ongoing training. The movement was carried out on August 13, 2020, starting with an introduction to journalism, and the action was continued again on August 27, 2020, with the subject of getting to know the news. This activity increased students' understanding of the definition, the function of the press, the form of mass media, the purpose of the report, types of information, and the value of the news shown in statistical data. This activity is also a pilot project for the Faculty of Communication Sciences at Tarumanagara University in managing the target area.
\end{abstract}

Keywords: Education, Journalism, Digital Generation

\begin{abstract}
ABSTRAK
Generasi digital adalah generasi yang hampir keseluruhan kehidupannya bergantung kepada akses internet. Kemudahan mengakses informasi memiliki sisi negatif dan positif. Sisi negatif adalah generasi digital adalah generasi yang rawan akan kriminalitas siber dan mudah terpapar hoaks melalui jaringan internet, sudah banyak riset dalam Ilmu Komunikasi yang membahas sisi negatif dari berkembangnya teknologi. Namun disisi lain generasi digital mampu menciptakan konten-konten melalui media sosial yang menarik. Potensi Inilah yang digagas oleh SMA Kristen Kanaan untuk menciptakan ekstrakurikuler yang mampu meningkatkan kemampuan mahasiswa dalam dunia jurnalistik. Permasalahan muncul ketika tidak tersedia sumber daya pengajar yang dapat memberikan edukasi dunia jurnalistik kepada siswa-siswi. Oleh sebab itu Fakultas Ilmu Komunikasi Universitas Tarumanagara berupaya untuk mencerdaskan kehidupan masyarakat melalui kegiatan pengabdian kepada masyarakat (PKM), untuk membantu Sekolah SMA Kristen Kanaan dalam menjalankan ekstrakurikuler jurnalistik dengan memberikan pelatihan secara berkelanjutan. Kegiatan dilakukan pada tanggal 13 Agustus 2020 diawali dengan pengenalan tentang Jurnalistik dan kegiatan dilanjutkan lagi pada tanggal 27 Agustus 2020 dengan pokok bahasan mengenal berita. Hasil dari kegiatan ini adalah terdapat peningkatan pemahaman siswa-siswa terkait definisi, fungsi pres, bentuk media massa, definisi berita, jenis berita, dan nilai berita yang ditunjukkan dalam data statistik. Selain itu kegiatan ini menjadi pilot project bagi Fakultas Ilmu Komunikasi Universitas Tarumanagara dalam mengelola wilayah binaan.
\end{abstract}

Kata Kunci: Edukasi, Jurnalistik, Generasi Digital

\section{PENDAHULUAN}

Komunikasi adalah upaya sistematis untuk merumuskan secara tegas asas-asas penyampaian informasi serta pembentukan pendapat dan sikap. Definisi ini menunjukkan bahwa yang dijadikan objek studi ilmu komunikasi busa saja penyampaian informasi melainkan juga pembentukan pendapat dan sikap publik yang ada dalam kehidupan sosial. Hovland mengatakan komunikasi 
adalah proses mengubah perilaku orang lain. Lebih lanjut Hovland berpandangan komunikasi untuk mengubah perilaku seseorang yaitu masalah bagaimana cara seseorang atau kelompok berperilaku tertentu (Ruliana, 2016).

Definisi lain terkait Komunikasi adalah suatu proses sosial individu menggunakan simbol untuk membangun dan menginterpretasikan makna dalam lingkungan mereka, melalui unsur komunikasi termediasi dengan peran teknologi dalam masyarakat kontemporer (Turner, 2017). Lebih lanjut Tuner menekankan pada lima aspek yang penting dalam komunikasi yaitu: sosial, proses, simbol, makna, dan lingkungan. Seperti pada Gambar 1.

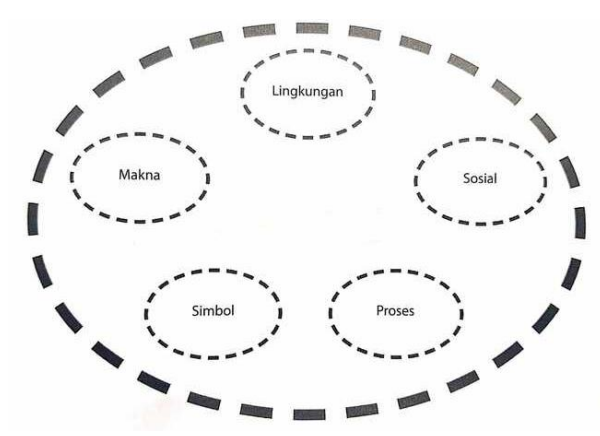

Gambar 1. Proses Komunikasi (Sumber: West \& Turner, 2017)

1) Komunikasi merupakan bentuk sosial adalah sebuah gagasan bahwa individu dan interaksi merupakan bagian dari proses komunikasi. Dalam interaksi tersebut keduanya memainkan peran integral dalam proses komunikasi.

2) Komunikasi merupakan sebuah proses kejadian yang berkelanjutan, dinamis, dan tak berujung sehingga menciptakan sebuah makna.

3) Makna merupakan ekstrak dari pesan. Pesan komunikasi dapat memiliki lebih dari satu makna dan bahkan beberapa lapisan makna.

4) Simbol merupakan label yang diberikan atas sebuah fenomena. Kata-kata adalah simbol untuk sebuah konsep. Simbol biasanya disepakati dalam suatu kelompok, tetapi bisa saja simbol tersebut tidak dipahami oleh kelompok lain.

5) Lingkungan adalah situasi atau konteks dimana komunikasi itu terjadi. Lingkungan mencangkup sejumlah elemen, termasuk, waktu, tempat, periode, sejarah, hubungan, dan latar belakang budaya pembicaraan dan pendengar (West \& Turner, 2017).

Kreativitas merupakan cara berpikir sesuatu yang baru yang belum pernah ada. Kreativitas sebagai kemampuan untuk mengembangkan dan menggabungkan ide-ide baru dalam memecahkan permasalahan yang dihadapi (Hadiyati, 2011). Lebih lanjut kreativitas adalah inisiatif terhadap suatu produk atau proses yang berguna, bermanfaat, tepat, dan bernilai terhadap suatu tugas yang bersifat heuristis. Heuristis merupakan pedoman, petunjuk, atau panduan yang tidak lengkap yang akan menuntun kita untuk mengerti, mempelajari, atau menemukan sesuatu yang baru (Hadiyati, 2011).

Dalam komunikasi, kreativitas dibutuhkan untuk menyampaikan ide-ide terbaru kepada khalayak. Dengan komunikasi yang baik ide-ide tersebut akan tersampaikan dengan jelas dan masyarakat dapat memahami ide-ide tersebut. Hal tersebut sama dengan membuat karya tulis khususnya di media massa. Untuk menulis karya di media massa siswa-siswa harus mengetahui Nilai peristiwa apakah mengandung nilai berita. Nilai berita meliputi Waktu yang tepat (timeless), memiliki dampak terhadap orang banyak (impact), menyangkut suatu lembaga atau seseorang yang diketahui orang banyak (prominence), peristiwa yang diberitakan memiliki kedekatan kepada 
khalayak secara emosional ataupun geografis (proximity), suatu peristiwa atau kejadian yang dituliskan harus memiliki suatu konflik (conflict), kejadian yang jarang terjadi di kehidupan sehari-hari (the unusual), dan pemberitaan mengenai hal- hal yang sedang menjadi bahan pembicaraan orang banyak (the currency) (Elga \& Christi, 2020). Lebih lanjut berita merupakan laporan mengenai fakta atau ide terbaru dari suatu peristiwa, menarik dan atau penting bagi sebagian besar khalayak, dan disampaikan melalui media berkala seperti surat kabar, radio, televisi, atau media Online (Lavenia \& Utami, 2020).

Dalam membuat karya tulis dari ide pikiran hingga menjadi bentuk tulisan, merupakan runtutan logika yang menarik. Tidak banyak orang dapat membuat buat tulisan yang menarik. Terlebih lagi tingkat literasi masyarakat di Indonesia masih rendah. UNESCO pada tahun 2017 menempati posisi ke-60 dari 61 negara yang diteliti. Berdasarkan asumsi bahwa rendahnya tingkat literasi berkorelasi positif dengan kurangnya pengetahuan, keahlian, keterampilan, dan terlebih kemauan untuk melakukan verifikasi terhadap informasi yang diterima (Mudjiyanto, 2019). Oleh sebab itu, peran Perguruan Tinggi dalam mencerdaskan tingkat literasi menjadi lebih penting. Fakultas Ilmu Komunikasi Universitas Tarumanagara, sebagai perguruan tinggi yang memperhatikan hal tersebut, berencana untuk melakukan sosialisasi kepada siswa-siswi sekolah untuk meningkatkan cara menulis di sekolah.

Terdapat beberapa penelitian yang mengangkat tema literasi siswa dari lintas disiplin ilmu. Seperti penelitian yang dikembangkan oleh Early Grade Reading Assessment (EGRA). Asesmen ini untuk mengukur secara sistematis seberapa baik siswa di kelas-kelas awal sekolah pada tahun 2012 kepada 4.233 siswa kelas 3 di 184 sekolah yang tersebar di 7 provinsi. Penelitian itu menunjukkan siswa kelas 3 dapat membaca kata dalam Bahasa Indonesia, namun mereka belum tentu paham apa yang mereka baca. Hanya setengah dari para siswa itu yang mampu memahami tulisan dengan baik, yaitu mereka yang membaca dengan tingkat yang memuaskan (mampu menjawab sedikitnya 4 dari 5 pertanyaan dengan benar) (Solihin, Bakti, Pratiwi, \& Novirina, 2019). Sekolah sebagai sebuah inkubator kreativitas masih menemui kesulitan dalam membantu siswa-siswinya untuk membuat karya tulis yang dapat dipublikasi di media massa. Dengan dipublikasinya karya tulis siswa-siswi tersebut dapat menumbuhkan rasa bangga untuk siswa-siswa, sehingga menulis akan menjadi hal yang menarik.

Berdasarkan analisis situasi yang telah dijelaskan di atas, maka tim PKM membuat sebuah uraian mengenai rumusan permasalahan yang dihadapi oleh mitra, yaitu pertama, siswa-siswi SMA Kristen Kanaan, memiliki kegiatan ekstrakurikuler broadcasting dan kejurnalistikan yang tidak berkembang. Kedua, tidak adanya guru yang memiliki pengalaman untuk menulis di media massa. Berdasarkan permasalahan mitra di atas untuk menambah kemampuan menulis bagi Siswa-siswi Sekolah SMA Kristen Kanaan yang terletak di Jl. Kran No.7 9 6, RT.9/RW.6, South Gunung Sahari, Kemayoran, Central Jakarta City, Jakarta 10610 yang terlatak $8 \mathrm{~km}$ dari Universitas Tarumanagara.

\section{METODE PELAKSANAAN PKM}

Metode pelaksanaan yang digunakan dalam kegiatan ini meliputi beberapa langkah berikut ini:

1) Prodi Ilmu Komunikasi telah melakukan Kerja sama dengan Sekolah SMA Kristen Kanaan dalam bentuk pelatihan melalui ekstrakurikuler broadcasting dan kejurnalistikan.

2) Tim PKM Fikom Untar melakukan korespondensi dengan Prodi untuk dapat memberikan pelatihan pada ekstrakurikuler tersebut. Prodi memberikan jadwal kepada Tim PKM untuk mengisi pertemuan minggu pertama dan minggu kedua. 
3) Tim berdiskusi untuk menyesuaikan tema PKM dengan kebutuhan mitra dalam hal ini adalah SMA Kristen Kanaan.

4) Pelaksanaan pelatihan untuk siswa-siswi di sekolah SMA Kristen Kanaan "Komunikasi Kreatif Dalam Menulis Di Media Massa"

5) Monitoring dan evaluasi oleh Lembaga Penelitian dan Pengabdian Kepada Masyarakat Universitas Tarumanagara.

6) Laporan kegiatan.

Secara terperinci kegiatan PKM ini akan dilaksanakan dalam beberapa tahap, yaitu pertama adalah tahap pra kegiatan yang meliputi audiensi dan diskusi dengan mitra; tahap kedua adalah pelaksanaan kegiatan; dan tahap terakhir adalah pasca pelaksanaan kegiatan yang meliputi luaran PKM dan monitoring serta evaluasi. Gambar 2 adalah gambar tahapan dari metode pelaksanaan kegiatan PKM ini.

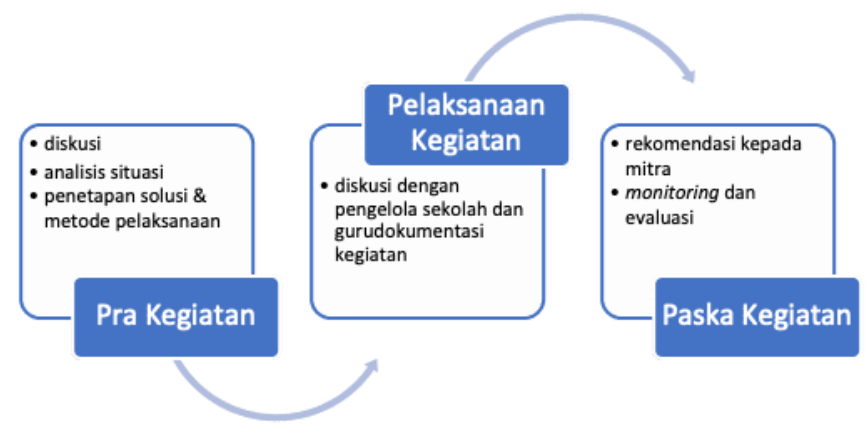

Gambar 2. Tahapan Kegiatan PKM

\section{HASIL DAN PEMBAHASAN}

Sekolah SMA Kristen Kanaan dipilih oleh Tim sebagai tempat melaksanakan kegiatan pengabdian kepada masyarakat. Alasan pemilihan tersebut sebagai berikut:

1. Sekolah SMA Kristen Kanaan berpartisipasi dalam pertemuan kepada sekolah se Jabodetabek yang diselenggarakan Universitas Tarumanagara pada 4 Maret 2020

2. Sebagai tindak lanjut dari kunjungan tersebut, Fakultas Ilmu Komunikasi Universitas Tarumanagara telah memiliki Kerja sama dengan sekolah tersebut dalam mengembangkan kegiatan ekstrakurikuler broadcasting dan kejurnalistikan di sekolah tersebut.

3. Selain itu lokasi sekolah SMA Kristen Kanaan juga dekat dengan Universitas Tarumanagara. Berdasarkan penelusuran Googlemap jarak Universitas Tarumanagara dengan sekolah SMA Kristen Kanaan sekitar 8 km. Lokasi SMA Kristen Kanaan beralamat di Jalan Kran No 7,6,9 RT.9/RW.6 Gn Sahari, Kecamatan Kemayoran Jakarta Pusat.

Dari kerja sama tersebut, Tim PKM mendapat kesempatan oleh Fakultas Ilmu Komunikasi untuk mengisi dua kali pertemuan kegiatan ekstrakurikuler broadcasting dan kejurnalistikan. Hal tersebut disambut baik oleh Tim PKM. Tim kemudian menyesuaikan kegiatan PKM sesuai dengan kebutuhan sekolah terkait tema yang disepakati. Sebelumnya tema pengabdian kepada masyarakat yang diajukan ke Lembaga Penelitian dan Pengabdian Kepada Masyarakat (LPPM) Universitas Tarumanagara adalah "Komunikasi Kreatif dalam Menulis Media Massa Untuk Siswa-Siswi SMA Marie Joseh" tema PKM ini menekankan pada cara menulis di media massa berganti menjadi "Komunikasi Kreatif dalam Media Massa di Sekolah SMA Kristen Kanaan" tema PKM ini lebih 
fokus kepada aspek jurnalistik dan pemberitaan. Seluruh kegiatan pengabdian kepada masyarakat ini dilakukan seluruhnya secara online dengan menggunakan aplikasi Zoom Meeting. Berikut ini adalah tema kegiatan PKM yang disepakati dan telah direalisasikan:

1. Mengenal Jurnalistik, Kamis 13 Agustus 2020

2. Mengenal Berita, Kamis 27 Agustus 2020

\subsection{Pelaksanaan Kegiatan}

Mengenal Jurnalistik Kegiatan pertama dengan tema Mengenal Jurnalistik diselenggarakan pada Kamis, 13 Agustus 2020 dengan jumlah 48 siswa. Berikut ini adalah proses pelaksanaan kegiatan:

1. Pemaparan diawali dengan definisi terkait jurnalistik, fungsi pers, bentuk media massa, dan perbedaan jurnalistik lama dan jurnalistik baru.

2. Sesi diskusi

3. Sesi Quis dengan menggunakan aplikasi Kahoot.

Dokumentasi kegiatan pertemuan pertama dapat dilihat pada Gambar 3.

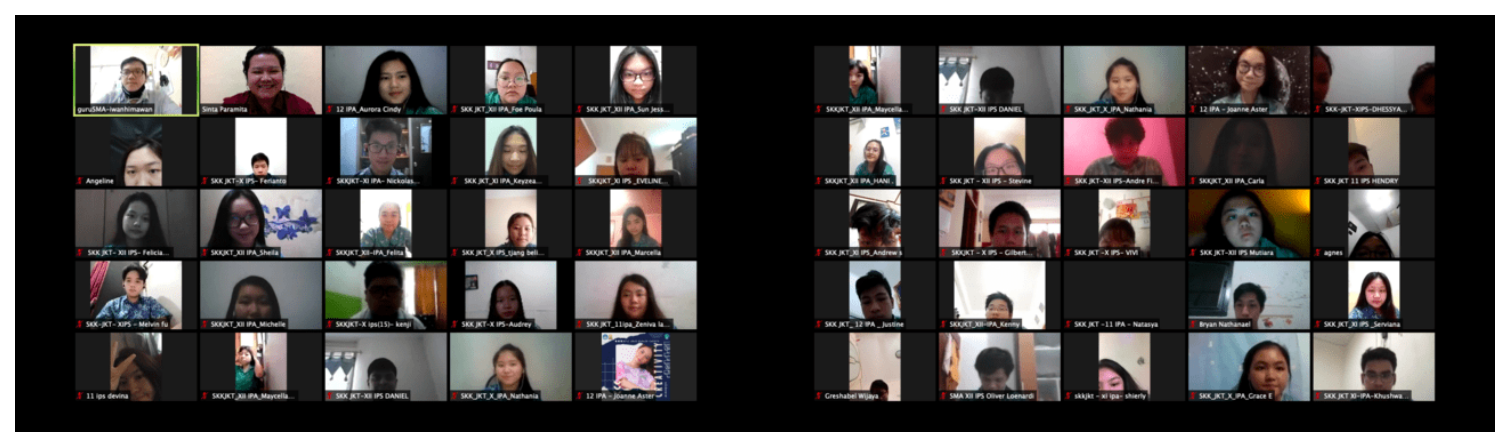

Gambar 3. Dokumentasi Kegiatan Pertemuan 1 Sumber: Dokumentasi Tim

Mengenal Berita kegiatan pertama dengan tema Mengenal Jurnalistik diselenggarakan pada Kamis, 27 Agustus 2020 dengan jumlah 47 siswa. Berikut ini adalah proses pelaksanaan kegiatan:

4. Pemaparan diawali dengan definisi terkait berita, jenis berita, nilai berita media cetak dan Online berita atau opini.

5. Sesi diskusi

6. Mengisi Kuesioner evaluasi hari pertama dan kedua.

Dokumentasi kegiatan pertemuan kedua dapat dilihat pada Gambar 4.

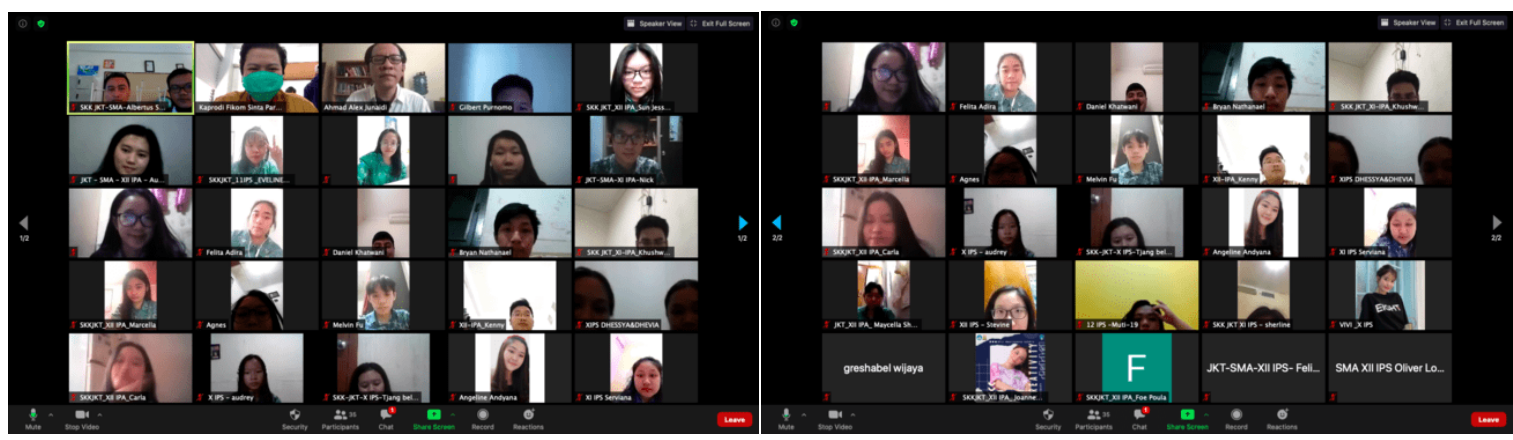

Gambar 4. Dokumentasi Kegiatan Pertemuan 2 Sumber: Dokumentasi Tim 
Tim pengabdian kepada masyarakat Fikom Untar membagikan kuesioner sederhana terkait evaluasi hari pertama dan kedua kepada peserta. Tujuan dari memberikan kuesioner ini adalah untuk mengetahui keberhasilan dari sebuah program pengabdian kepada masyarakat. Responden yang menjawab kuesioner sebanyak 33 peserta. Pertanyaan pertama dari kuesioner tersebut adalah pengetahuan tentang jurnalistik sebelum dan sesudah mengikuti kegiatan PKM ini. Sebelum mengikuti kegiatan ekstrakurikuler sebanyak $78.8 \%$ peserta tidak mengetahui definisi jurnalistik. Setelah mengikuti kegiatan ekstrakurikuler ini pemahaman peserta meningkat menjadi $87.7 \%$ memahami definisi dari jurnalistik yang akan ditunjukkan pada Gambar 5.

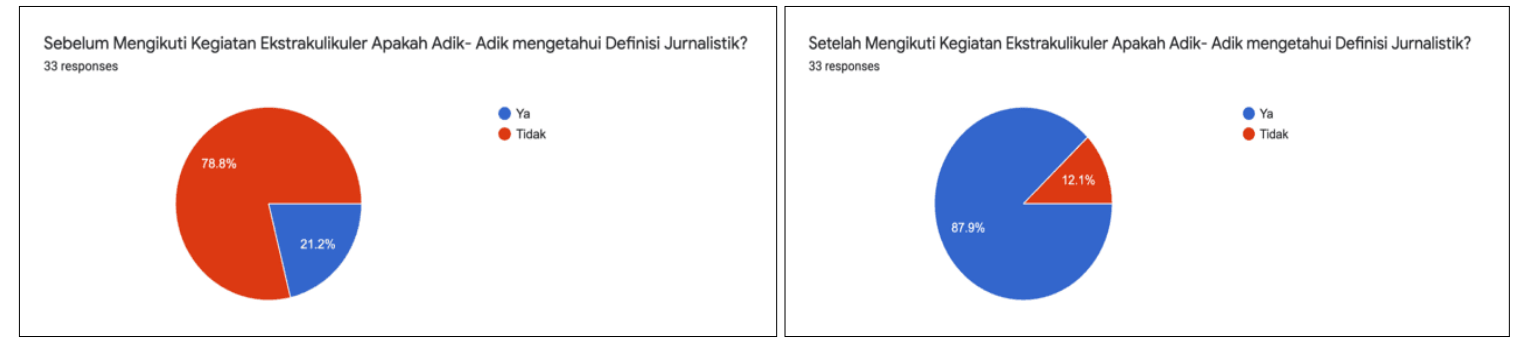

Gambar 5. Pengetahuan Definisi Jurnalistik

Sumber: Dokumentasi Tim

Pertanyaan kedua dari kuesioner tersebut adalah pengetahuan tentang fungsi pers sebelum dan sesudah mengikuti kegiatan PKM ini. Sebelum mengikuti kegiatan ekstrakurikuler sebanyak $84.4 \%$ peserta tidak mengetahui fungsi pers. Setelah mengikuti kegiatan ekstrakurikuler ini pemahaman peserta meningkat menjadi $81.3 \%$ peserta memahami fungsi pers yang akan ditunjukkan pada Gambar 6.

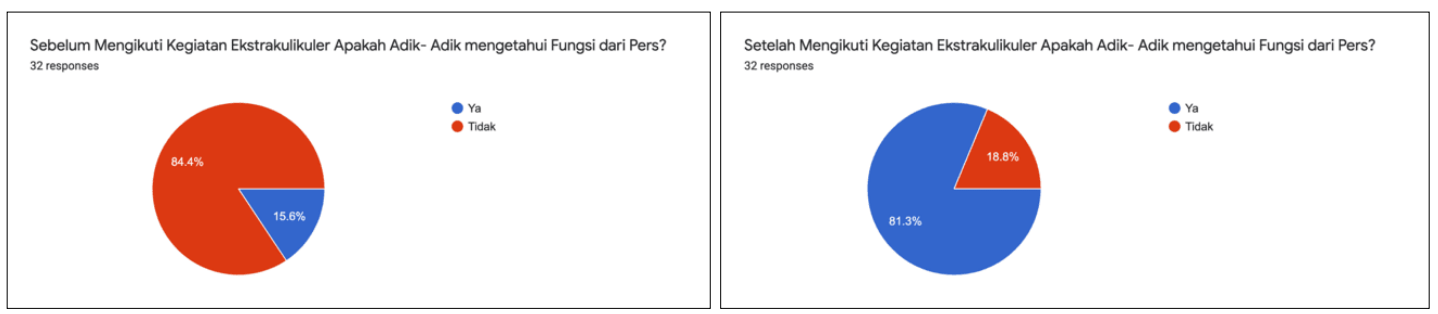

Gambar 6. Pengetahuan Fungsi Pers

Sumber: Dokumentasi Tim

Pertanyaan ketiga dari kuesioner tersebut adalah pengetahuan tentang bentuk media massa sebelum dan sesudah mengikuti kegiatan PKM ini. Sebelum mengikuti kegiatan ekstrakurikuler sebanyak $56.7 \%$ peserta tidak mengetahui bentuk media massa. Setelah mengikuti kegiatan ekstrakurikuler ini pemahaman peserta meningkat menjadi $87.5 \%$ peserta memahami fungsi pers yang akan ditunjukkan pada Gambar 7.

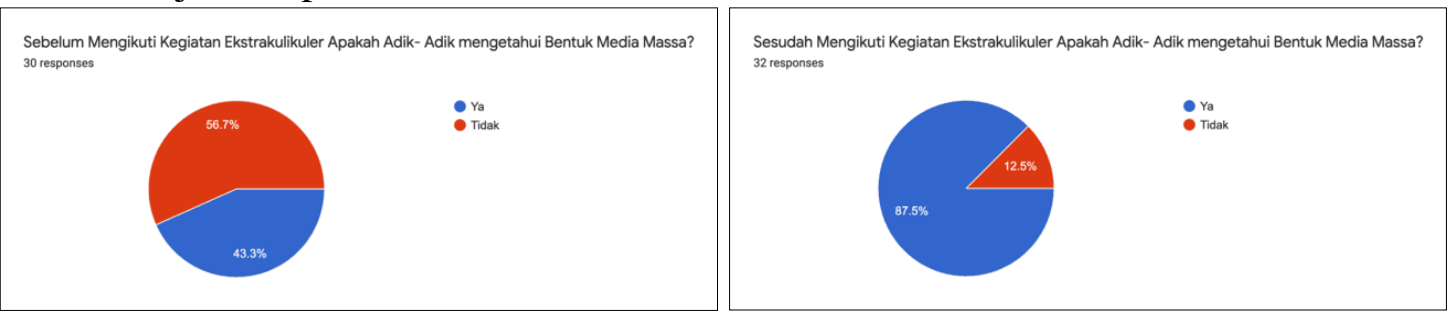

Gambar 7. Pengetahuan Bentuk Media Massa

Sumber: Dokumentasi Tim 
Pertanyaan keempat dari kuesioner tersebut adalah pengetahuan tentang berita sebelum dan sesudah mengikuti kegiatan PKM ini. Sebelum mengikuti kegiatan ekstrakurikuler sebanyak 56.3\% peserta tidak mengetahui definisi berita. Setelah mengikuti kegiatan ekstrakurikuler ini pemahaman peserta meningkat menjadi $90 \%$ peserta memahami definisi berita yang akan ditunjukkan pada Gambar 8.

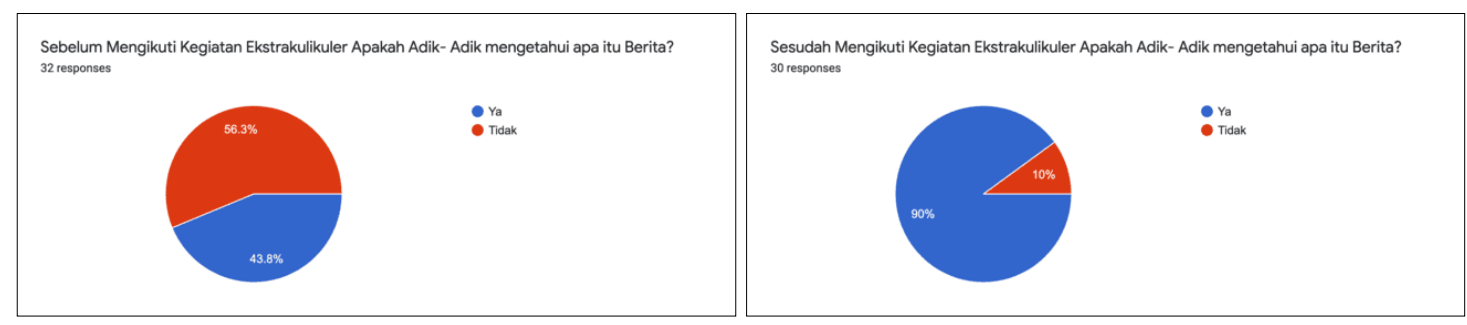

Gambar 8. Pengetahuan Definisi Berita

Sumber: Dokumentasi Tim

Pertanyaan kelima dari kuesioner tersebut adalah pengetahuan tentang jenis berita sebelum dan sesudah mengikuti kegiatan PKM ini. Sebelum mengikuti kegiatan ekstrakurikuler sebanyak $75 \%$ peserta tidak mengetahui jenis berita. Setelah mengikuti kegiatan ekstrakurikuler ini pemahaman peserta meningkat menjadi $78.8 \%$ peserta memahami jenis berita yang akan ditunjukkan pada Gambar 9.

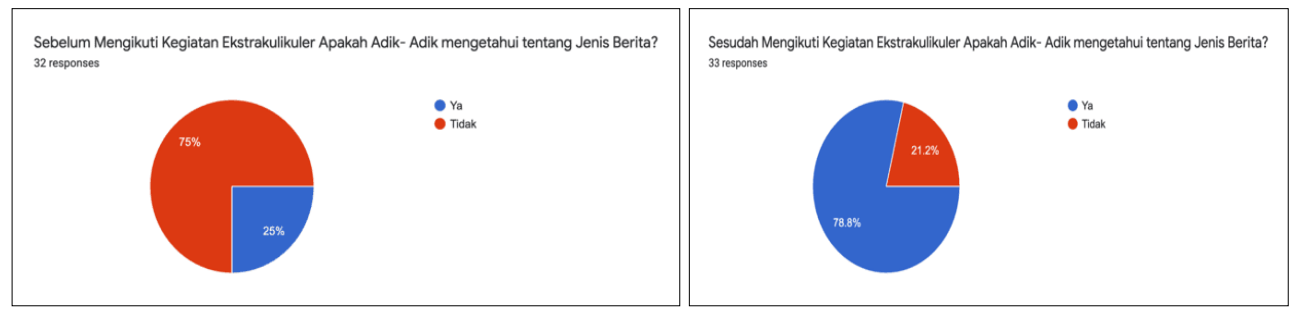

Gambar 9. Pengetahuan Jenis Berita

Sumber: Dokumentasi Tim

Pertanyaan keenam dari kuesioner tersebut adalah pengetahuan tentang nilai berita sebelum dan sesudah mengikuti kegiatan PKM ini. Sebelum mengikuti kegiatan ekstrakurikuler sebanyak $81.3 \%$ peserta tidak mengetahui nilai berita. Setelah mengikuti kegiatan ekstrakurikuler ini pemahaman peserta meningkat menjadi $84.8 \%$ peserta memahami nilai berita yang akan ditunjukkan pada Gambar 10.

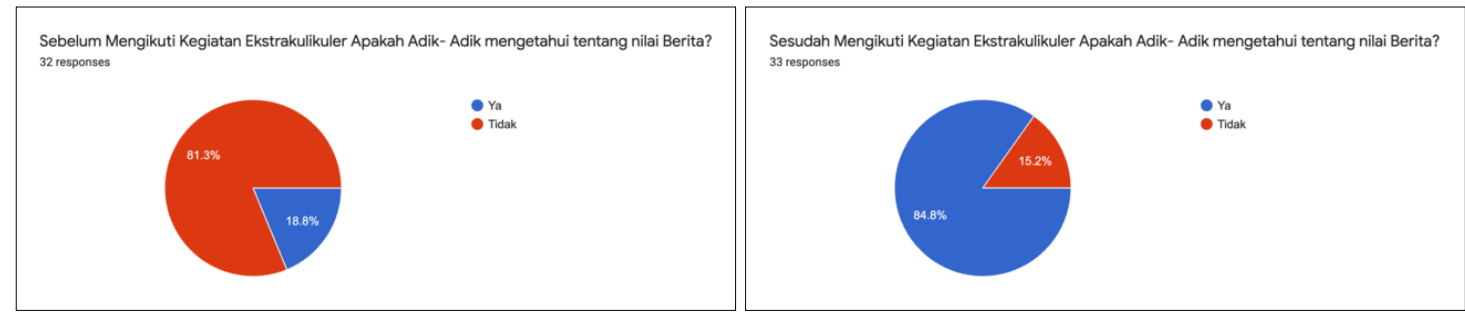

Gambar 10. Pengetahuan Nilai Berita

Sumber: Dokumentasi Tim

\section{KESIMPULAN DAN SARAN}

Kesimpulan dari kegiatan Edukasi Pengenalan Jurnalitik kepada Generasi Digital di Sekolah SMA Kristen Kanaan bisa dikatakan berhasil. Terjadi peningkatan pemahaman terkait definisi, fungsi 
press, bentuk media massa, definisi berita, jenis berita, dan nilai berita bagi siswa-siswi SMA Kristen Kanaan.

\section{Ucapan Terima Kasih (Acknowledgement)}

Ucapan terima kasih diberikan kepada para peserta murid dan guru SMA Kristen Kanaan, Lembaga Penelitian dan Pengabdian Masyarakat Universitas Tarumanagara, Fakultas Ilmu Komunikasi dan Prodi Ilmu Komunikasi Universitas Tarumanagara yang selalu mendukung terselenggaranya Tri Dharma Perguruan Tinggi khususnya pada bidang pengabdian kepada masyarakat.

\section{REFERENSI}

Elga, H., \& Christi, J. (2020). Analisis Kode Etik Jurnalistik Pemberitaan Keberagaman di Media Online. Koneksi (Vol. 4). Retrieved from https://journal.untar.ac.id/index.php/koneksi/article/view/6495

Hadiyati, E. (2011). Kreativitas dan Inovasi Berpengaruh Terhadap Kewirausahaan Usaha Kecil. Jurnal Manajemen Dan Kewirausahaan, 13(1), 8-16. https://doi.org/10.9744/jmk.13.1.8-16

Lavenia, L., \& Utami, L. S. S. (2020). Pemberitaan Kasus PT PLN (Persero) di Media Siber dan Penerapan Kode Etik Jurnalistik (Analisis Framing Pemberitaan Blackout Listrik 4 Agustus 2019 di Okezone.Com). Koneksi (Vol. 3). Retrieved from https://journal.untar.ac.id/index.php/koneksi/article/view/6493

Mudjiyanto, B. (2019). HOAKS DALAM BINGKAI BLACK CAMPAIGN. Majalah Ilmiah Semi Populer Komunikasi Massa, 15(2), 103-116. Retrieved from https://jurnal.kominfo.go.id/index.php/MKM/article/viewFile/2806/1285

Solihin, L., Bakti, U., Pratiwi, I., \& Novirina. (2019). Indeks Aktivitas Literasi Membaca 34 Provinsi. Jakarta: Kepala Pusat Penelitian Kebijakan Pendidikan dan Kebudayaan. Retrieved from https://litbang.kemdikbud.go.id 